\title{
The importance of the nutrition and of the body weight index in the recovery of the patients older diagnosed with coxarthrosis
}

\author{
Sînziana Călina Silișteanu ${ }^{1}$ MD, Andrei Emanuel Silişteanu² Stud
}

${ }^{1}$ Railway Hospital Iasi - Specialty Ambulatory of Suceava - "Stefan cel Mare" University of Suceava ${ }^{2}$ Cluj School of Public Health - FSPAC - Babeş-Bolyai University sinzi_silisteanu@yahoo.com

\section{ABSTRACT}

Introduction. Coxarthrosis is a degenerative health condition at the hip level, frequently occurred in adults, especially in 2 to $4 \%$ of the persons who are 50 to 70 years old. Coxarthrosis reduces the joint mobility with consequences upon the walking perimeter and upon steadiness, with severe dysfunctions and negative effects upon the quality of life. It is very important for the patient to avoid putting on weight (possibly losing weight), to avoid using the orthostatism for too long and to avoid walking on rough grounds. Twenty to thirty per cent of the Romanian population are obese. Nutrition is very important for the elderly, that is why they must have an adequate weight by balanced nutrition and by physical activities adapted to the age and to pathology, which might ensure "a healthy and active old age". Objectives. The objectives of this paper are to point out the role of the body weight index and of the adjacent parameters as well as the role of the kinetic therapy in the recovery of the patients diagnosed with coxarthritis. Methodes. The current trial was carried in the outpatient department throughout the year 2016 on a number of 74 patients with the age over 50. According to the medical guides, the recovery means were represented by the medication treatment, electrical therapy, decontracturing massage, kinetic therapy . Results. The results for VAS scale were statistically significant for both groups and for all the evaluation moments. For the pain, rigidity and physical dysfunction parameters (WOMAC scale), the obtained results for both groups and for all the evaluation moments are statistically significant. Conclusions. The complex treatment enabled the increase in the joint mobility at the level of the knock knee joints, by providing with steadiness, balance and the recovery of the walk. The body weight index and the nutritional status are elements that might influence the recovery of the patients diagnosed with coxarthritis; therefore, they are parameters that must be taken into account within the complex recovery programme.

Key words: coxarthrosis, body weight index, the quality of life, recovery.

\section{Introduction}

Coxarthrosis is a degenerative health condition at the hip level, frequently occurred in adults, especially in 2 to $4 \%$ of the persons who are 50 to 70 years old [1]. From an etiological point of view, $40 \%$ of the coxarthrosis cases are primitive [2], [3]. Other factors are also involved: heredity, the hormonal status, the nutritional status, the professional activity and the muscular hypotony [4].

Coxarthrosis reduces the joint mobility with consequences upon the walking perimeter and upon steadiness, with severe dysfunctions and negative effects upon the quality of life [2], [5], [6]. The evolution of this disease is very slow and progressive [5], with moments of worsening and remission; this is why it is important to use a complex recovering treatment according to the pathology of every single patient [7].

The objectives of the recovery treatment in coxarthrosis are: to reduce the pain and the anti-inflammatory process, to recover the joint mobility at the knock knees, to recover the balance and the possibility to walk, to ensure steadiness of the hip [2], to prevent any disabilities from occurring and to increase the quality of life [4], [8], [9], [10]. It is very important for the patient to avoid putting on weight (possibly losing weight), to avoid using the orthostatism for too long and to avoid walking on rough grounds. According to World Health Organisation, 
the aging is a physiological processand it consists of progressive irreversible modifications of the living substance [11]. At the same time, there is also a pathology characteristic to this age group: the coronarian disease, brain vascular diseases, aterosclerosis, deafness, osteoporosis, spondilosis and other degenerative diseases at the joint level. In relation to this age group, it is important to mention the issues related to disabilities, the social addiction with demographic, economic and social consequences and the medical care. Before 2010, the number of less than five-year-old children was higher than the number of the persons who were over 65 years old; however, this report is expected to be reversed in the following 10 years due to the increase in life expectancy and by the aging of the population. The number of the elderly is expected to rise from 524 million in 2010 to approximately 1.5 billion in 2050 [12].

The elderly go through physiological modifications that affect the biochemical indicators, the eating habits and the nutritional needs. Thus, there may be a lack of balance between the intake and the energy consumption, by exceeding the nutritional needs, an eating abuse that may lead to overweight and obesity. Twenty to thirty per cent of the Romanian population are obese [13]. The energy need for the elderly decreases by approximately 7 kcalories a year for women and 10 kcalories a year for men [14].

Nutrition is very important for the elderly, that is why they must have an adequate weight by balanced nutrition and by physical activities adapted to the age and to pathology, which might ensure "a healthy and active old age". Therefore, it is recommended that the kinetic therapy sessions should be held at home, too.

Obesity is a medical issue but also a social one because the medical costs represent approximately 1 to $3 \%$ of the overall expenses in the health system. The prevalence of obesity is rising: over $18 \%$ of the the world population was diagnosed with obesity in 2015.
Obesity represents the increase in the body weight, especially because of the adipose tissue, so that the body weight index (IMC) is higher than $30 \mathrm{~kg} / \mathrm{m}^{2}$ [11], [12]. It is widely known that the obesity rate got doubled from 1980 to 2015 and it included about 200 million men and 300 million women [16]. Therefore, many countries implemented public policies to prevent the population from becoming obese [17].

The body weight index (IMC) is the most used formula in order to evaluate the weight excess. According to the World Health Organisation, the body weight index is calculated according to the formula weight / height ${ }^{2}$ whereas the normal values are from 18.5 to $24.9 \mathrm{~kg} / \mathrm{m}^{2}$. The values from 25 to $29.9 \mathrm{~kg} / \mathrm{m}^{2}$ match the overweight persons whereas the values over $30 \mathrm{~kg} / \mathrm{m}^{2}$ match the obese population (the first group from 30 to $34.9 \mathrm{~kg} / \mathrm{m}^{2}$, the second group from 35 to $39.9 \mathrm{~kg} / \mathrm{m}^{2}$ and the third group over 40 $\mathrm{kg} / \mathrm{m}^{2}$ [15], [16], 18],[19].

Also, in order to evaluate the nutritional status, it is important to consider the abdomen circumference; the values over 102 $\mathrm{cm}$ for men and over $88 \mathrm{~cm}$ for women are associated to the risk of cardiovascular diseases [16], [18], [19], [20], [21].

\section{Objectives}

The objectives of this paper are to point out the role of the body weight index and of the adjacent parameters as well as the role of the kinetic therapy in the recovery of the patients diagnosed with coxarthrosis.

\section{Material and method}

The current trial was carried in the outpatient department throughout the year 2016 on a number of 74 patients. The inclusion criteria were: the age over 50, the $\mathrm{x}$-ray and clinical diagnosis of coxarthrosis, patients who accepted to be included in the study. The exclusion criteria were: the age under 50 and over 80, chronic conditions, psychical conditions and the refusal of the patients to take part in this trial.

According to the medical guides, the recovery means were represented by the medication treatment (AINS, anti-algic and decontracturing), electrical therapy (galvanic 
power, interferential power and ultrasound), heat therapy (short waves), decontracturing massage, kinetic therapy (exercises for the increase in the joint mobility, the improvement of the peri-joint muscular force and the improvement of the balance between agonists and antagonists). The 74 patients were divided into two groups which received a complex pharmacological treatment, electrical therapy and massage. In addition, the second group also made kinetic therapy.

The evaluation of the patients was made at the beginning of the treatment, 20 twenty days after the treatment and at the control two months later. It included the visual analogue scale (VAS) of the pain, the WOMAC scale for the evaluation of the pain, of the rigidity and of the physical dysfunction, the joint balance for the knock knee joint, the abdomen circumference and the perimeter for the thighs.

\section{Results}

The first group included 38 patients (50\% men and $50 \%$ women) whereas the second group included 34 patients (36.11\% women and 63.89 men), as it can be seen in Table no. 1 and Graph no. 1.

\begin{tabular}{|l|l|c|c|c|}
\hline Group & Gender/Age & $50-60$ years old & $61-70$ years old & $71-80$ years old \\
\hline \multirow{2}{*}{ Group 1 } & Women & 8 & 9 & 2 \\
\cline { 2 - 5 } & Man & 14 & 3 & 2 \\
\hline \multirow{2}{*}{ Group 2 } & Women & 6 & 5 & 2 \\
\cline { 2 - 5 } & Man & 16 & 5 & 2 \\
\hline
\end{tabular}

Table no. 1: The distribution of the patients according to their age group and gender

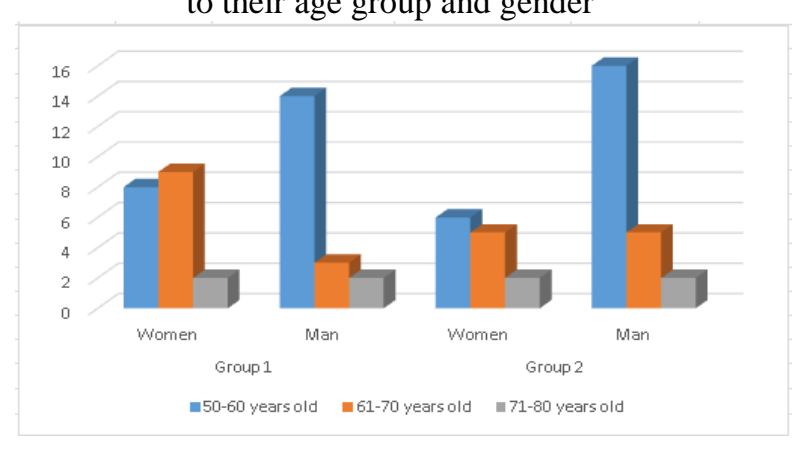

Graph no. 1: The distribution of the patients according to their age group and gender The pain was evaluated according to the VAS scale whereas the results are shown in Table no. 2 and in Graph no. 2

\begin{tabular}{|l|l|r|r|r|}
\hline Group & VAS initial & VAS initial & VAS final & \multicolumn{1}{l|}{ VAS control } \\
\hline Group 1 & mediana & 7 & 5 & 3 \\
\cline { 2 - 6 } & devstd & 1,622214211 & 1,353831295 & 1,27705431 \\
\cline { 2 - 6 } & test t-std & 0,023271056 & 0,057699234 & 0,018292417 \\
\hline Group 2 & mediana & 7 & 5 & 3 \\
\cline { 2 - 6 } & devstd & 1,614419154 & 0,950772451 & 0,7740842 \\
\cline { 2 - 6 } & test t-std & 0,023218289 & 0,044464792 & 0,015157714 \\
\hline
\end{tabular}

Table no. 2: The evolution of the data obtained for the VAS scale

The results were statistically significant for both groups and for all the evaluation moments except for the first group for the final / control moment.

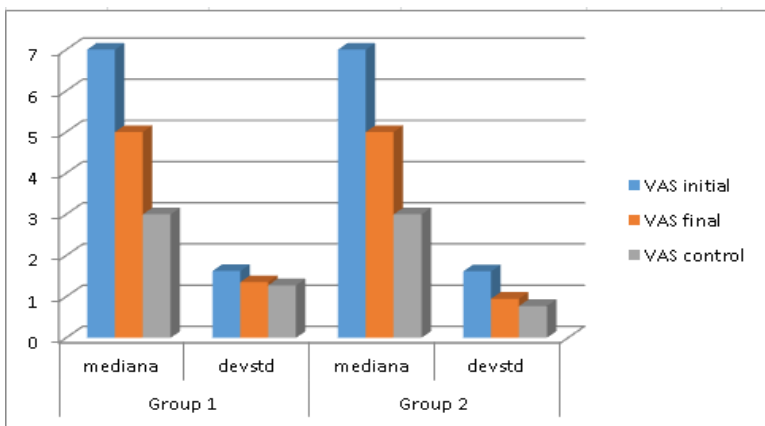

Graph no. 2: The evolution of the data obtained for the VAS scale

The WOMAC scale enabled the evaluation of the pain, of the rigidity and of the physical dysfunction whereas the results are shown in Table no. 3 and Graph no. 3-5.

For the pain, rigidity and physical dysfunction parameters, the obtained results for both groups and for all the evaluation moments are statistically significant, except for the first group. For the rigidity parameter, the result is statistically insignificant for the final / control moment. For the same parameter, it is statistically insignificant for the second group for the initial / control moment. 


\begin{tabular}{|c|c|c|c|c|c|c|c|c|c|c|}
\hline \multirow[t]{2}{*}{ Group } & \multirow{2}{*}{$\begin{array}{l}\text { WOMAC/ Statistics } \\
\text { ELEMENTS }\end{array}$} & \multirow{2}{*}{\begin{tabular}{|l} 
Pain \\
initial \\
\end{tabular}} & \multirow[b]{2}{*}{ final } & \multirow[b]{2}{*}{ control } & \multirow{2}{*}{\begin{tabular}{|l} 
Rigidity \\
initial \\
\end{tabular}} & \multirow[b]{2}{*}{ final } & \multirow[b]{2}{*}{ control } & \multicolumn{3}{|c|}{ Physical dysfunctions } \\
\hline & & & & & & & & initial & \begin{tabular}{|l|l} 
final & \\
\end{tabular} & control \\
\hline \multirow[t]{3}{*}{ First group } & median & 14 & 10 & 5,5 & 6 & 4 & 2 & 46 & 27 & 15 \\
\hline & dev std & 1,178578 & 0,589742 & 0,506712 & 0,687213 & 0,577556 & 0,226294 & 9,290017 & 3,100039 & 1,166447 \\
\hline & test t-std & 0,015759 & 0,042665 & 0,010577 & 0,024383 & 0,062385 & 0,019738 & 0,046838 & 0,044989 & 0,028384 \\
\hline Second & median & 14 & 10 & 5,5 & 7 & 5 & 3 & 30 & 22,5 & 15 \\
\hline \multirow[t]{2}{*}{ group } & dev std & 1,046157 & 0,467177 & 0,559904 & 0,494413 & 0,478091 & 0,494413 & 11,54618 & 7,228032 & 2,527782 \\
\hline & test t-std & 0,01541 & 0,04231 & 0,010293 & 0,015678 & 0,036162 & 0,008722 & 0,029992 & 0,044239 & 0,019058 \\
\hline
\end{tabular}

Table no. 3: The evolution of the data obtained for the WOMAC scale - Pain

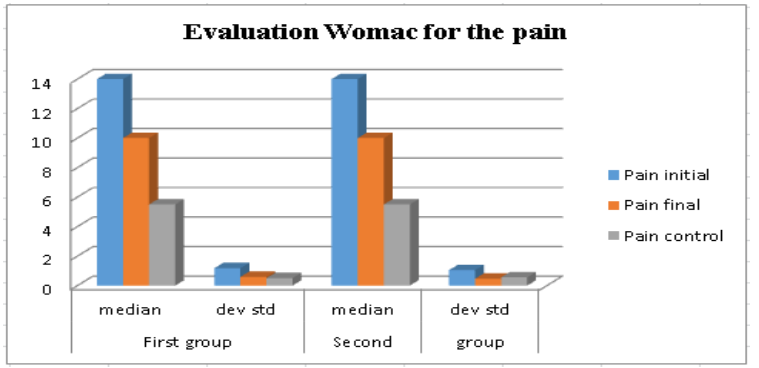

Graph no. 3: The evolution of the data obtained for the WOMAC scale - Pain

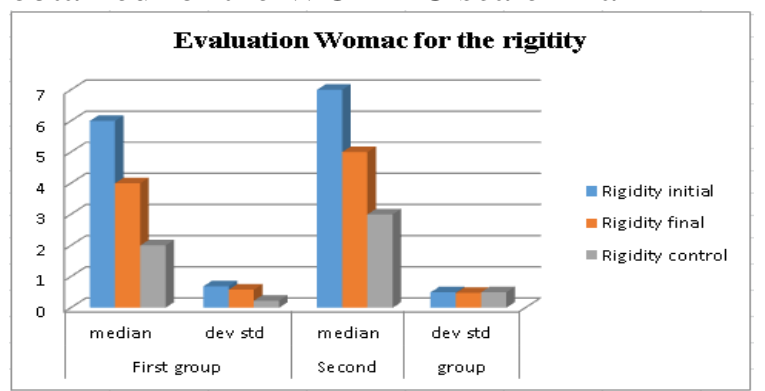

Graph no. 4: The evolution of the data obtained for the WOMAC scale - Rigidity

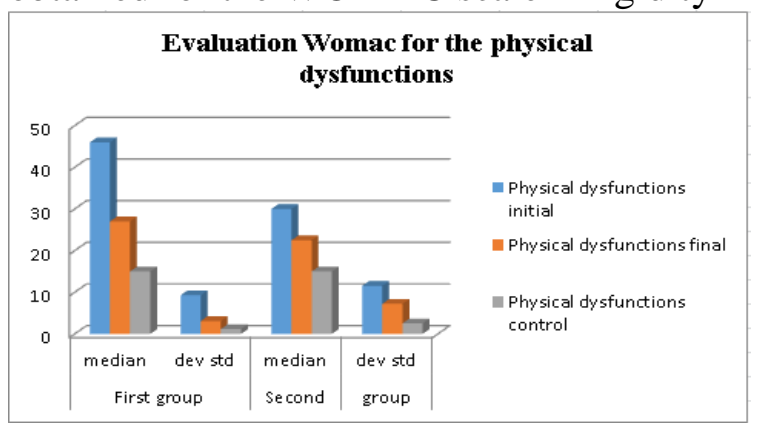

Graph no. 5: The evolution of the data obtained for the WOMAC scale - Physical dysfunctions. After measuring the perimeters at the thigh level, the obtained values are shown in Table no. 4-5.

\begin{tabular}{|l|l|r|r|r|}
\hline Group & perimeter thigh/ & right & \\
\cline { 2 - 5 } & statistic elements & initial & final & control \\
\hline \multirow{2}{*}{ First } & median & 28 & 30 & 32 \\
\hline group & dev std & 18,90988 & 18,59807293 & 20,28747 \\
\cline { 2 - 5 } & test t-student & 0,004808 & 0,006293481 & 0,00053 \\
\hline \multirow{2}{*}{$\begin{array}{l}\text { Second } \\
\text { group }\end{array}$} & median & 46 & 46,5 & 44,5 \\
\cline { 2 - 5 } & dev std & 5,838904 & 5,692570346 & 6,176938 \\
\cline { 2 - 5 } & test t-student & $2,07 \mathrm{E}-05$ & 0,000337797 & $1,75 \mathrm{E}-07$ \\
\hline
\end{tabular}

Table no. 4: The evolution of the data obtained for the thigh perimeter -right

\begin{tabular}{|l|l|l|r|r|}
\hline Group & perimeter thigh/ & \multicolumn{3}{l|}{ left } \\
\cline { 2 - 5 } & statistic elements & initial & final & control \\
\hline First & median & 40 & 45 & 30 \\
\cline { 2 - 5 } group & dev std & 18,62695 & 18,52709001 & 17,14352 \\
\cline { 2 - 5 } & test t-student & 0,005375 & 0,060353232 & 0,005162 \\
\hline \multirow{2}{*}{$\begin{array}{l}\text { Second } \\
\text { group }\end{array}$} & median & 48 & 43,5 & 42 \\
\cline { 2 - 5 } & dev std & 5,099652 & 5,110427404 & 4,985588 \\
\cline { 2 - 5 } & test t-student & 0,001525 & 0,000199114 & $1,29 \mathrm{E}-05$ \\
\hline
\end{tabular}

Table no. 5: The evolution of the data obtained for the thigh perimeter -left

For all the moments of the right thigh in comparison to the left thigh, the results for both groups are statistically significant, except for the first group. For the left thigh, the obtained result is statistically insignificant. The values for the body weight index for the two groups are shown in Table no. 6 and in Graph no. 6

\begin{tabular}{|l|l|l|l|l|}
\hline \multirow{2}{*}{ Group } & Statistic elements & $\begin{array}{l}\text { Initial } \\
\text { body } \\
\text { weight } \\
\text { index }\end{array}$ & $\begin{array}{l}\text { Final } \\
\text { body } \\
\text { weight } \\
\text { index }\end{array}$ & $\begin{array}{l}\text { Control } \\
\text { body } \\
\text { weight } \\
\text { index }\end{array}$ \\
\hline First & median & 30,615 & 30,09 & 29,575 \\
\hline \multirow{2}{*}{ group } & dev std & 4,447001 & 4,445679 & 4,318996 \\
\cline { 2 - 5 } & test t-student & $5,13 \mathrm{E}-05$ & $5,43 \mathrm{E}-05$ & $5,82 \mathrm{E}-08$ \\
\hline \multirow{2}{*}{$\begin{array}{l}\text { Second } \\
\text { group }\end{array}$} & median & 28,27 & 27,38 & 26,525 \\
\cline { 2 - 5 } & dev std & 3,493262 & 3,456532 & 3,41445 \\
\hline & test t-student & 0,000167 & 0,000166 & $5,89 \mathrm{E}-07$ \\
\hline
\end{tabular}

Table no. 6: The evolution of the data obtained for the values of the body weight index

The results obtained for the evaluation of the body weight index are statistically significant for both groups and for the evaluation moments.

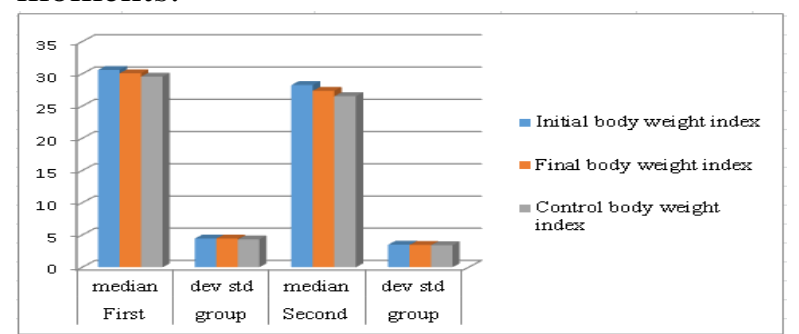

Graph no. 6: The evolution of the data obtained for the values of the body weight index 
As for the nutritional status, the data are shown in Table no. 7.

\begin{tabular}{|l|l|l|l|l|r|r|r|}
\hline \multirow{2}{*}{ Group } & Evaluation moment/ & Initial & \multicolumn{2}{l|}{ Final } & \multicolumn{2}{l|}{ Control } \\
\cline { 2 - 8 } & status & women & man & women & man & women & man \\
\hline \multirow{2}{*}{ First } & Normal weight & 0 & 1 & 0 & 1 & 0 & 1 \\
\cline { 2 - 8 } & Overweight & 10 & 7 & 10 & 7 & 10 & 7 \\
\cline { 2 - 8 } & First degree obesity & 6 & 10 & 6 & 10 & 6 & 10 \\
\cline { 2 - 8 } & Second degree obesity & 0 & 0 & 0 & 0 & 0 & 0 \\
\cline { 2 - 8 } & Third degree obesity & 2 & 2 & 2 & 2 & 2 & 2 \\
\hline \multirow{3}{*}{ Second } & Normal weight & 4 & 1 & 8 & 1 & 10 & 5 \\
\cline { 2 - 7 } & Overweight & 11 & 10 & 9 & 11 & 10 & 8 \\
\cline { 2 - 8 } & First degree obesity & 5 & 3 & 5 & 2 & 2 & 1 \\
\cline { 2 - 8 } & Second degree obesity & 2 & 0 & 0 & 0 & 0 & 0 \\
\cline { 2 - 7 } & Third degree obesity & 0 & 0 & 0 & 0 & 0 & 0 \\
\hline
\end{tabular}

Table no. 7: The evolution of the data obtained for the nutritional status

The patients' evaluated nutritional status shows that the persons with the third degree obesity who have a decreased value of the body weight index need to follow a long term kinetic therapy programme whereas the daily menu should be correlated to the daily activity and to the rate of the basal metabolism. For the women in the second group, it is found that the body weight index is gradually reduced, which is obvious in the low number of the persons with the second degree obesity as well as in the corresponding increase in the number of the overweight persons and of the normal weight persons, in comparison to the women in the first group whose reduction is limited. It is found in the second group that the number of the male patients with the first degree obesity is low. After making the joint balance for the flexion of the thigh on both sides, the results are shown in Table no. 8 .

\begin{tabular}{|l|l|l|r|r|r|r|r|}
\hline Group & Thigh flexion/ & right & \multicolumn{1}{l|}{ left } \\
& Statistical elements & initial & final & control & initial & final & control \\
\hline \multirow{2}{*}{$\begin{array}{l}\text { First } \\
\text { group }\end{array}$} & median & 60 & 67,5 & 80 & 58 & 66 & 70 \\
\cline { 2 - 9 } & dev std & 28,872 & 30,575 & 33,394 & 27,655 & 26,566 & 27,17 \\
\cline { 2 - 8 } & test t-std & 0,0063 & 0,0114 & 0,0015 & 0,0412 & 0,01314 & 0,005 \\
\hline \multirow{3}{*}{$\begin{array}{l}\text { Second } \\
\text { group }\end{array}$} & median & 63 & 77,5 & 90 & 65,5 & 76,5 & 89,5 \\
\cline { 2 - 8 } & dev std & 30,529 & 29,418 & 28,519 & 26,58 & 26,2825 & 26,56 \\
\cline { 2 - 8 } & test t-std & 0,0155 & 0,0064 & 0,0019 & 0,0074 & 0,00647 & $9 \mathrm{E}-04$ \\
\hline
\end{tabular}

Table no. 8: The evolution of the data obtained for the joint mobility thigh - flexion

The results obtained for the first group for the evaluation of the joint mobility measured in the flexion of the thigh show statistically significant values at the right thigh for the final / control moment as well as at the left one for the initial / final moment and for the final / control moment. They are extremely significant for the initial / final moment and for the initial / control moment at the right thigh and for the initial / control moment at the left thigh.
The results obtained for the second group are extremely significant for both thighs except for the initial / final moment at the right thigh where the result is statistically significant.

\section{Conclusions}

- The complex treatment enabled the increase in the joint mobility at the level of the knock knee joints, by providing with steadiness, balance and the recovery of the walk;

- The evaluation according to the WOMAC scale enabled the emphasis of the decrease in the pain and rigidity parameter and it improved the joint mobility;

- The complex recovery treatment may reduce the length of the recovery treatment; if it is correlated to the reduction of the body weight index, it may lead to the increase in the quality of these patients' lives;

- The kinetic programme adapted to the pathology of each patient enables a continuous mobility of the joints and it provides with an adequate nutritional status.

The body weight index and the nutritional status are elements that may influence the recovery of the patients diagnosed with coxarthrosis; this is why they are parameters that must be taken into account within the complex recovery programme. 


\section{References}

[1] ONOSE, G., (2008) - Compendiu de neuroreabilitare la adulţi, copii şi vârstnici, Edit. Universitară "Carol Davila", Bucureşti, pg. 231-238;

[2]Nica. AS Compendiu de medicină fizică şi recuperare, Editura Universitară „Carol Davila” Bucureşti, 1998

[3] Ancuţa C.-Esenţialul în Medicina Fizică şi Recuperare Medicală, Editura „Gr.T.Popa”-UMF Iaşi-2010

[4] Sînziana Călina Silişteanu -The influence of the body weight index (BMI) in the recovery of the degenerative diseases of the joints, Balneo Research Journal DOI: http://dx.doi.org/10.12680/balneo.2016.120 Vol.7, No.2, May 2016

[5] Popescu R., Trăistariu R., Badea P. - Ghid de evaluare clinică și funcțională în recuperarea medicală, Ed. Medicală Universitară, Craiova, 2004

[6]Ivan G, Coxartroza, Editura Scrisul Românesc, Craiova, 1982

[7] Silisteanu, S.C.; Covasa, M. "Assisting the quality of life for old age persons (over 65 years old) with disabilities", Computational Intelligence for Multimedia Understanding (IWCIM), 2015 International Workshop

[8]Lupu, I. (2006). Calitatea vieţii în sănătate. Definiţii şi instrumente de evaluare. Calitatea vieţii, vol. 17, nr. 1-2: 1-21 [9]SBENGHE,T., (2002) - Kinesiologie - Ştiinţa mişcării, Edit. Medicală, Bucureşti, pg. 263; 178, 326, 376-395

[10] Rădulescu A. - Electroterapie, Ed. Medicală, 2003

[11]Beers MH, Berkov R (Eds). The Merck Manual of Geriatrics. 3rd edn. Whitehouse Station NJ, Merck Research Laboratories 2000.

[12] World Health Organization. Global health and aging. In National Institute on Aging and National Institutes of Health 2011;1-32

[13] Health status overview for countries of central and eastern Europe that are candidates for accession to the European Union 2006.

[14] Ross AC, Caballero B, Cousins R , et al. Modern nutrition in health and disease. 11 th ed 2006

[15] AHA/ACC/TOS Guideline for the Management of Oveweight and Obesity in Adults, 2013: A Report of the American College of Cardiology/American Heart Association Task Force on Practice Guidelines and The Obesity Society. Circulation 2013; 1-69.

[16] Harvard School of Public Health - Obesity Prevention Source

[17] Organisation for Economic Co-operation and Development, Obesity Update 2014

[18] Watson RR. Nutrition in the prevention and treatment of abdominal obesity. Elsevier 2014.

[19] Coulston AM, Boushey CJ, Mario G.FerruzziMG. Nutrition in the prevention and treatment of desease. Elsevier 2013

[20] Aronne LJ.Classifiaction of obesity and assessment of obesity-related health risks. Obes Res 2002;10 (Suppl 2):105S-115S.

[21]Pi-Sunyer FX.The obesity epidemic:pathophysiology and consequences of obesity. Obes Res 2002; 10(Suppl 2):97S$104 S$. 